\title{
Results of species hybridization with Quercus robur L and Quercus petraea (Matt) Liebl
}

\begin{abstract}
S Steinhoff
Lower Saxony Forest Tree Breeding Department, Forstamtstraße 6, W- 3513 Escherode, Germany

Summary - Quercus robur and Quercus petraea can be crossbred. The hybridization rate is affected by the fact that $Q$ robur is more easy fertilized with $Q$ petraea pollen than vice versa, and the fact that individual incompatibilities hinder pollination. The fertilization rate of intraspecific crosses was about $21.6 \%$ (with a pollen mixture) and $12.6 \%$ (with single-tree pollen) for $Q$ robur and $13.7 \%$ (pollen mixture) and $17.6 \%$ (single-tree pollen) for $Q$ petraea. Interspecific crosses had fertilization rates of $6.5 \%$ (pollen mixture) and $11.5 \%$ (single-tree pollen) for $Q$ robur and $9.2 \%$ (pollen mixture) and $1.8 \%$ (single-tree pollen) for $Q$ petraea. After selecting clones that readily accepted pollen from the other species, the fertilization rate increased greatly, especially for the combination $Q$ petraea $\mathrm{x}$ $Q$ robur (single-tree pollen). Dried pollen can be stored at $-18^{\circ} \mathrm{C}$.
\end{abstract}

Quercus robur L / Quercus petraea (Matt) Liebl / hybridization / cross breeding

Résumé - Résultats des hybridations contrôlées entre Quercus robur $L$ et Quercus petraea (Matt) Liebl. Quercus robur et Quercus petraea sont des espèces compatibles. Cependant le croisement de $\mathrm{Q}$ robur avec du pollen de $\mathrm{Q}$ petraea est plus facile que le croisement inverse; d'autre part le taux d'hybridation dépend aussi des phénomènes d'incompatibilité au niveau individuel. Le taux d'hybridation dans les croisements intraspécifiques est de 21,6\% (mélange pollinique) et de 12,6\% (pollen d'arbres individuels) pour $Q$ robur. Ces chiffres sont respectivement $13,7 \%$ et $17,6 \%$ pour $Q$ petraea. Les mêmes taux au niveau des croisements interspécifiques sont de 6,5\% (mélange pollinique) et $11,5 \%$ (pollen d'arbres individuels) chez $Q$ robur et $9,2 \%$ (mélange pollinique) et $1,8 \%$ ( $p o /$ len d'arbres individuels) chez $Q$ petraea. Ces chiffres augmentent très nettement si on sélectionne les meilleures combinaisons (arbres les plus compatibles) surtout pour le croisement $Q$ petraea / $Q$ robur. Le pollen peut être conservé à $-18^{\circ} \mathrm{C}$.

Quercus robur $L$ / Quercus petraea (Matt) Liebl / hybridation / croisement contrôlé

\section{INTRODUCTION}

Both species $Q$ robur and $Q$ petraea grow in Germany. The geographical range of $Q$ petraea includes that of $Q$ robur. Their ecology is different, although mixed stands are common and intermediate types have al- ways been found (Krahl-Urban, 1959; Kleinschmit and Svolba, 1979). These forms were regarded as hybrids or as form variations of Quercus, mainly robur (Burger, 1921; Jovanovic and Tucovic, 1975; Wigston, 1975; Rushton, 1978; Kleinschmit and Svolba, 1979; Aas, 1988). 
In 1989 and 1990, a controlled crossing program of $Q$ robur and $Q$ petraea was initiated on the seed orchards of Berkel, near Hannover. The goals of this program are to obtain further information on the following questions : - How does the crossing technique for these species work? - What is the difference between the intra- and interspecific pollination rates? - What are the growth rate and survival percentage and how do the hybrids look?

\section{MATERIALS AND METHODS}

The $Q$ petraea and $Q$ robur seed orchards in Berkel were established in 1955 and 1957 with grafts from selected plus trees by Krahl-Urban. Isolation of the female strobili began with bud flushing. Male strobili and buds which did not have any female strobili were removed by hand. Branches with at least 5 female flowers (only the flower-bearing stems were counted) were isolated in paper-cellophane bags.

Just before natural pollen shedding, the pollen was collected in paper bags and dried in a ca $23^{\circ} \mathrm{C}$ warm room with low air humidity. After cleaning, the pollen was dried, separated by clone, and placed a second time in a ca $23^{\circ} \mathrm{C}$ warm room or the desiccator (for $4 \mathrm{~h}$ ). The pollen was stored for shorter periods (up to $2 \mathrm{wk}$ ) at $+1^{\circ} \mathrm{C}$ or, for long-term storage, at $-18^{\circ} \mathrm{C}$. A pollen sprayer with a rubber bulb, 2 pipes pressed through the rubber stopper into the pollen bottle and a needle to pierce the bag made the pollination unit. Pollination was done when the pistil was large, widely open, glossy and glutinous.

Pollen which was collected in 1989 and not needed for crossing that year was stored in glass bottles at $-18^{\circ} \mathrm{C}$. It was successfully used for pollination the following year.

\section{RESULTS}

In 1989, about 15000 female strobili were control-pollinated. Table I shows the crossing combinations and the number of suc- cessful combinations, the number of acorns produced and the measurements of the acorns. Many acorns were very small and did not germinate in the spring of 1990. Some loss of acorns was due to fungal damage. The hybrid combination $Q$ robur $\times Q$ petraea was more successful $(6.5 \%$ of the flowers pollinated with a pollen mixture and $11.5 \%$ of those pollinated with single-tree pollen produced acorns) than the combination $Q$ petraea $\times Q$ robur $(9.2 \%$ of the flowers pollinated with a pollen mixture and $1.8 \%$ of those pollinated with single-tree pollen produced acorns). The self-pollination rate for $Q$ robur was $1.9 \%$ and for $Q$ petraea it was very small, with only $0.6 \%$ acorns of pollinated flowers.

Table II shows the germination rate, growth during the 1st and 2nd years and the survival percentage for each year. Normally, the height of oak seedlings growth depends upon the size of the acorns and of the mother; the bigger the acorn the taller the seedlings, and $Q$ robur seedlings are taller than $Q$ petraea seedlings. Until now, the hybrids have not shown any significant differences from the pure species. Therefore, each acorn from the 1990 crossing was measured and weighted (table III).

En 1990 , a total of 4443 female flowers were isolated. On each mother tree, a pollen mixture and a tester pollen from both species were used for the pollination. In addition pair crossings were made. Table IV shows the 1990 campaign.

Acorns were stored after thermotherapy $\left(42^{\circ} \mathrm{C}\right.$ water soaking for $\left.2 \mathrm{~h}\right)$ in small bags in a cool house at $-1^{\circ} \mathrm{C}$ over winter. Many acorns were lost due to fungal damage and mice. Before sowing, the acorns were soaked in moderately warm water.

All differences in growth rate between seedlings from different crosses were attributable to the size of the acorns. 


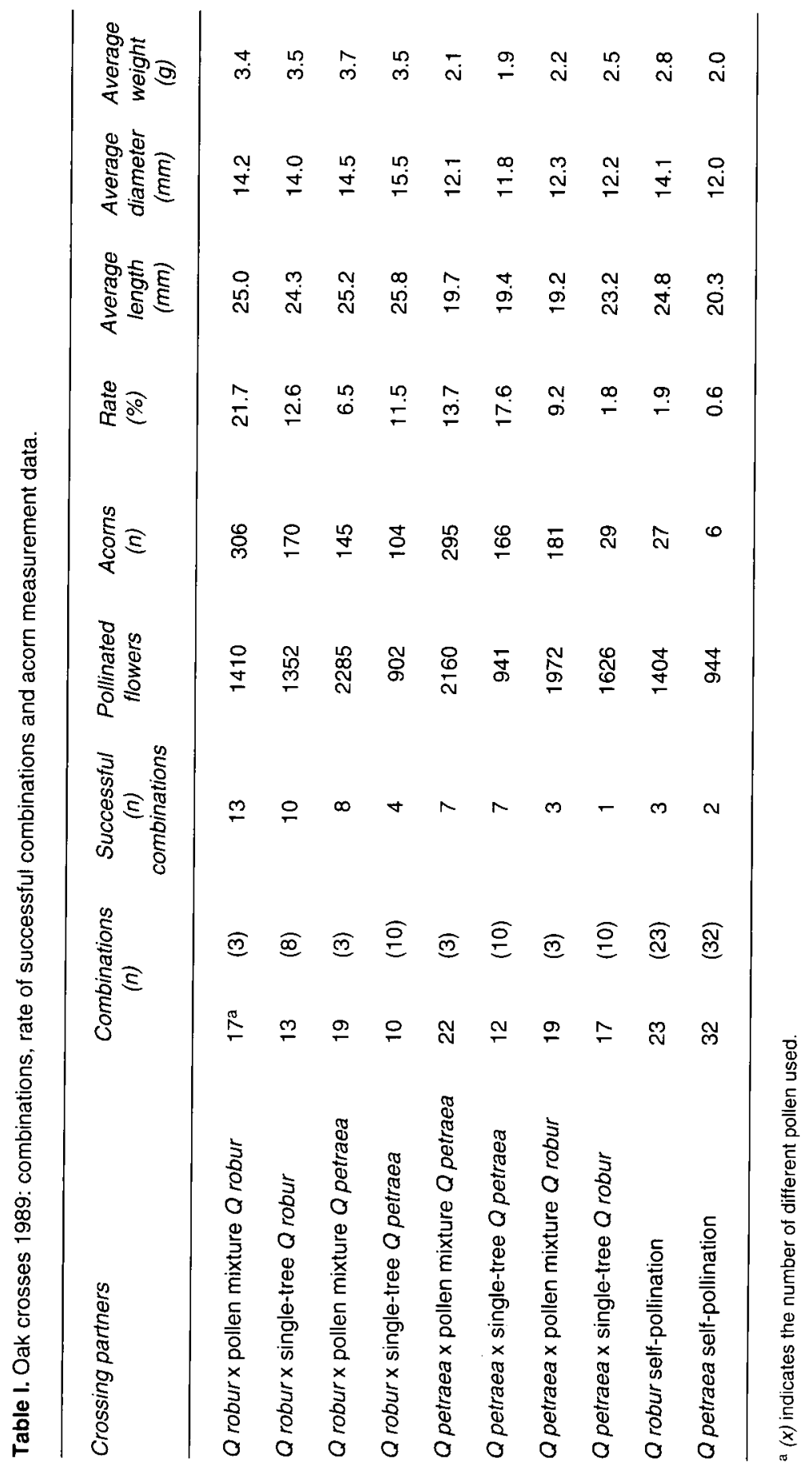




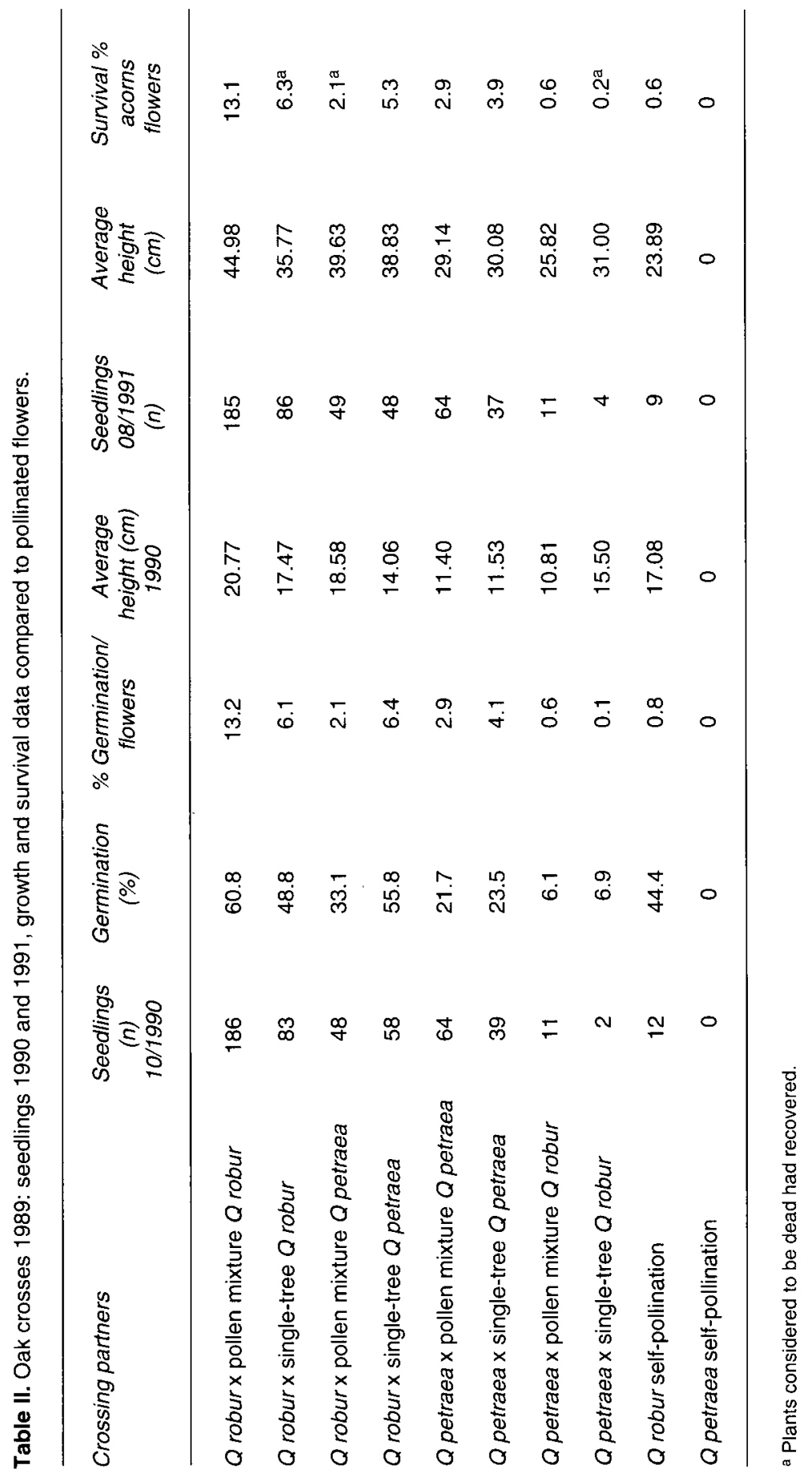




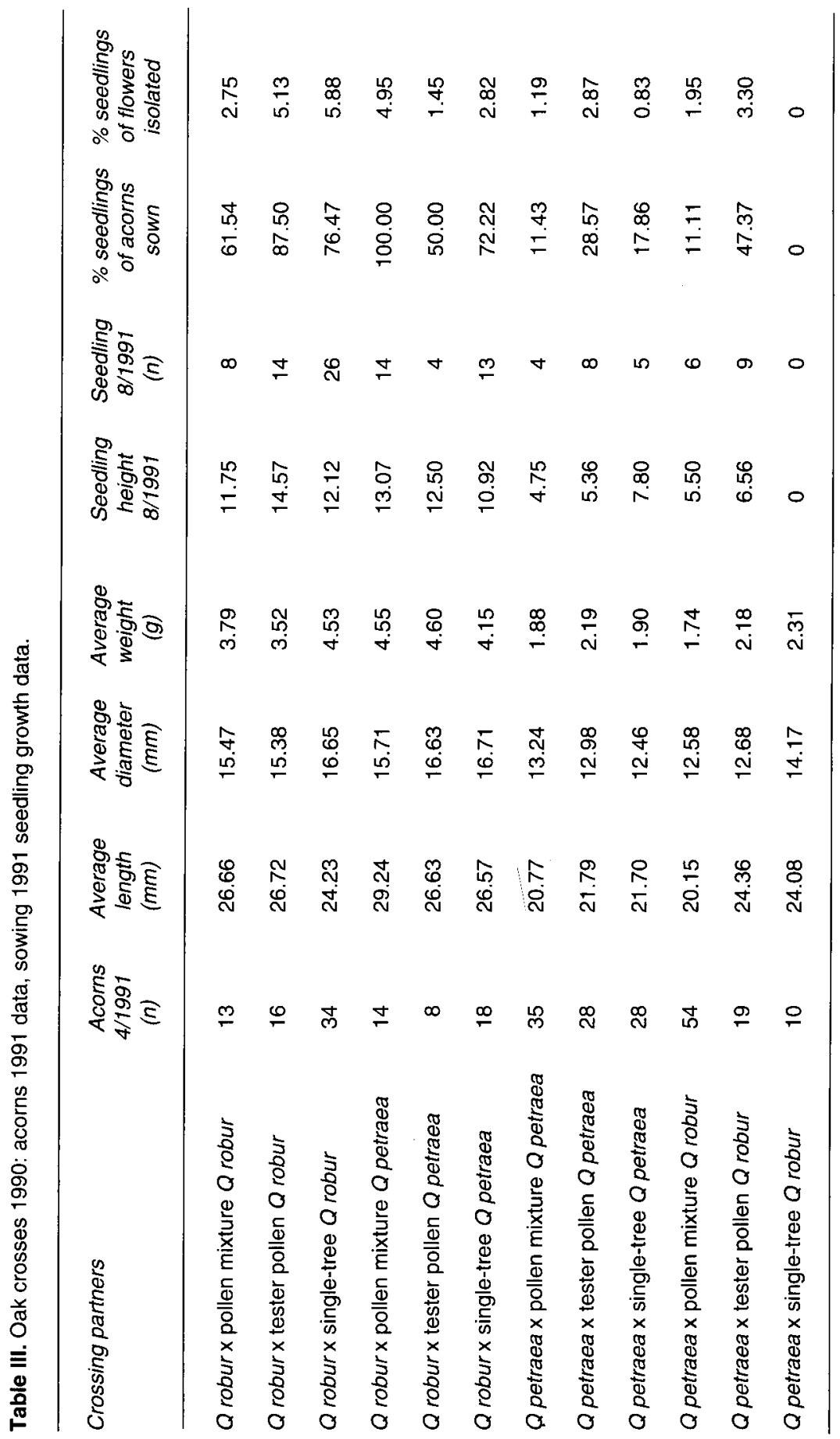


Table IV. Oak crosses 1990: combinations, rate of successful combinations, acorns achieved and rate of acorns compared to pollinated flowers.

$\begin{array}{cccccc}\text { Crossing partners } & \text { Combinations } & \text { Successful Pollinated } & \text { Acorns } & \text { Rate } \\ (n) & \text { combinations } & \text { flowers } & 10 / 1990 & (\%) \\ & & (n) & & (n) & \end{array}$

$\begin{array}{llrlrr}\text { Q robur x pollen mixture Q robur } & 11 & 6 & 291 & 26 & 8.94 \\ \text { Q robur x tester pollen Q robur } & 11 & 5 & 273 & 16 & 5.86 \\ \text { Q robur x single-tree Q robur } & 18 & 11 & 442 & 70 & 15.84 \\ \text { Q robur x pollen mixture Q petraea } & 11 & 4 & 283 & 21 & 7.42 \\ \text { Q robur x tester pollen Q petraea } & 11 & 5 & 275 & 24 & 8.72 \\ \text { Q robur x single-tree } Q \text { petraea } & 18 & 11 & 461 & 23 & 4,99 \\ \text { Q petraea x pollen mixture Q petraea } & 15 & 7 & 335 & 35 & 10.45 \\ \text { Q petraea x tester pol } Q \text { petraea } & 13 & 8 & 279 & 63 & 22.58 \\ \text { Q petraea x single-tree Q petraea } & 22 & 8 & 602 & 47 & 7.81 \\ \text { Q petraea x pollen mixture Q robur } & 13 & 6 & 308 & 68 & 22.08 \\ \text { Q petraea x tester pollen Q robur } & 13 & 3 & 273 & 68 & 7,69 \\ \text { Q petraea x single-tree } Q \text { robur } & 23 & 3 & 621 & 10 & 1,61\end{array}$

Morphologically, most of the seedlings resembled their mother. As long as the trees are juvenile, no statistical assesments will be made.

At this point, no significant indication for heterosis of interspecific hybrids can be observed, unlike those reported for other crossings in oak (Piatnitsky, 1960). The seedlings with $Q$ robur mothers had the bigger and heavier acorns and they grew bigger and faster than the seedlings who had a $Q$ petraea mother.

\section{DISCUSSION}

The isolation and pollination technique for oak was devised. The main problem was determining the optimal time for pollen collection. After drying, pollen was stored at $18^{\circ} \mathrm{C}$ and was successfully used for pollination the following year. Artificial crossing of $Q$ robur and $Q$ petraea produces fewer acorns $(0.2-13.1 \%$ of pollinated flowers) than natural pollination (16\%; Jovanovic and Tucovic, 1975). Quercus robur has higher reproduction rates when pollinated with pollen from $Q$ petraea than vice versa. Clones selected for their crossability with the other species have high reproduction rates in interspecific crossing. As $Q$ robur is morphologically the more variable species, it can only be surmised that the differences in crossability are due to introgression or variation due environmental factors (letswaart and Feij, 1989).

Clones selected from their original stands (pure, mixed or intermediate) and their leaf characters should be crossed.

\section{REFERENCES}

Aas $G$ (1988) Untersuchungen zur Trennung und Kreuzbarkeit von Stiel- und Traubeneiche (Quercus robur L und $Q$ petraea (Matt) Liebl. Dissertation, Universität München

Burger H (1921) Über morphologische und biologische Eigenschaften der Stiel- und Traubeneiche und ihre Erziehungsweise im Forstgarten. Mitt Schweiz Anst Forstl Versuchswas $11,306-377$ 
letswaart JH, Feij AE (1989) A multivariate analysis of introgression between Quercus robur and $Q$ petraea in The Netherlands. Acta Bot Neerl 38, 313-325

Jovanovic M, Tucovic A (1975) Genetics of common and sessile oak (Quercus robur $L$ and $Q$ petraea Liebl). Ann For 7, 23-53

Kleinschmit J, Svolba J (1979) Möglichkeiten der züchterischen Verbesserung von Stielund Traubeneichen (Quercus robur und Quercus petraea). III. Nachkommenschaftsprüfung von Eichenzuchtbäumen. Allg ForstJadgztg, vol 6, Sanderdruck
Krahl-Urban J (1959) Die Eichen. Paul PareyVerlag Hamburg

Piatnitsky SS (1960) Evolving new forms of oak by hybridization. Proceedings of the 5th World Forestry Congress 2, 815-817

Rushton BS (1978) Quercus robur $L$ and Quercus petraea (Matt) Liebl : a multivariate approach to the hybrid problem. 1. Data acquisition, analysis and interpretation. Watsonia 12, 81-101

Wigston DL (1975) The distribution of Quercus robur L, $Q$ petraea (Matt) Liebl and their hybrids in south-western England. Watsonia 10, 345-369 